\title{
MANAJEMEN PROGRAM TAHFIDZ AL-QURAN
}

\section{Yaya Suryana}

Universitas Islam Negeri Sunan Gunung Djati Bandung Jl. A.H. Nasution No. 105 Cibiru Bandung

Email: yayasuryana@uinsgd.ac.id

\section{Dian}

Universitas Islam Negeri Sunan Gunung Djati Bandung Jl. A.H. Nasution No. 105 Cibiru Bandung

Email: dian@uinsgd.ac.id

\section{Siti Nuraeni}

Universitas Islam Negeri Sunan Gunung Djati Bandung JI. A.H. Nasution No. 105 Cibiru Bandung

Email: sitinuraeni@uinsgd.ac.id

\section{ABSTRAK}

Pondok Pesantren Assalam melakukan integrasi program Tahfidz Aldengan pendidikan madrasah.Dengan terintegrasinya program Tahfidz AlQuran, maka diperlukannya pengelolaan program Tahfidz Al-Quran agar tujuan program Tahfidz Al-Quran tercapai serta berjalan secara efektif dan efesien. Tujuan penelitian untuk mengetahui : hasil yang dicapai dalam manajemen program Tahfidz Al Quran di Pondok Pesantren Tahfidz Al-Quran Assalaam. Penelitian ini menggunakan metode penelitian deskriptif kualitatif dan teknik pengumpulan data melalui wawancara, observasi, dokumentasi dan menyalin. Manajemen program Tahfidz Al-Quran dilakukan mulai perencanaan, pengorganisasian, pemotivasian, pengawasan dan evaluasi program sehingga program Tahfidz Al-Quran dapat berjalan secara efektif dan efesien. Pembenahan dalam pembelajaran, sumber daya manusia dan sarana prasarana pun terus dilakukan untuk meningkatkan kualitas pendidikan. Program Tahfidz Al-Quran di Pondok Pesantren Tahfidz Al-Quran Assalaam menghasilkan santri yang berprestasi, mandiri dan berakhlak mulia.

Kata kunci: Manajemen, Program Tahfidz Al-Quran

\section{ABSTRACT}

Assalam Islamic Boarding School integrates the Tahfidz Al-program with madrasa education. With the integration of the Tahfidz Al-Quran program, it is necessary to manage the Tahfidz Al-Quran program so that the objectives of the Tahfidz Al-Quran program are achieved and run effectively and efficiently. 
The research objective was to find out: the results achieved in the management of the Tahfidz Al Quran program at the Tahfidz Al-Quran Assalaam Islamic Boarding School. This study uses descriptive qualitative research methods and data collection techniques through interviews, observation, documentation and copying. The management of the Tahfidz Al-Quran program is carried out starting with planning, organizing, motivating, monitoring and evaluating programs so that the Tahfidz Al-Quran program can run effectively and efficiently. Improvements in learning, human resources and infrastructure continue to be carried out to improve the quality of education. The Tahfidz AlQuran program at Tahfidz Al-Quran Assalaam Islamic Boarding School produces students who are accomplished, independent and noble.

Keywords: Management, Tahfidz Al-Quran Program

\section{PENDAHULUAN}

Berdasarkan Undang-Undang No. 20 Tahun 2003 Bab 1 Pasal 1 Ayat 1 tentang Sistem Pendidikan Nasional, Pendidikan adalah usaha sadar dan terencana untuk mewujudkan suasana belajar dan proses pembelajaran agar siswa secara aktif mengembangkan potensi dirinya untuk memiliki kekuatan spiritual keagamaan, pengendalian diri, kepribadian, kecerdasan, akhlak mulia serta keterampilan yang diperlukan dirinya, masyarakat, bangsa dan negara.

Pendidikan adalah usaha yang dilakukan dengan sengaja dan sistematis untuk memotivasi, membina, membantu, dan membimbing seseorang untuk mengembangkan segala potensinya sehingga ia mencapai kualitas diri yang lebih baik. Inti dari pendidikan adalah usaha pendewasaan manusia seutuhnya (lahir dan batin), baik oleh orang lain maupun oleh dirinya sendiri, dalam arti tuntutan agar anak didik memiliki kemerdekaan berpikir, merasa, berbicara, dan bertindak serta percaya diri dengan penuh rasa tanggung jawab dalam setiap tindakan dan perilaku kehidupannya sehari-hari (Basri, 2013:14-15).

Pendidikan tidak akan terwujud tanpa adanya kerjasama satu sama lain yang saling berhubungan sehingga membentuk satu kesatuan (sistem). Maka dari itu pendidikan harus tersusun dan direncakan, sehingga sistem tersebut dapat berjalan dengan baik. Pengelolaan kegiatan pendidikan tersebut dikenal dengan istilah manajemen.

Menurut Weggner dan Hollenbeck yang dikutip oleh Maisah (2013:1), manajemen adalah suatu proses perencanaan, pengorganisasian dalam rangka mencapai tujuan melalui pembagian kerja. Sedangkan menurut Jaja Jahari dan Amirullah Sarbini (2013: 2) manajemen adalah suatu proses yang khas terdiri atas tindakan-tindakan berupa perencanaan, pengorganisasian, penggerakan dan pengendalian yang dilaksanakan untuk menentukan serta mencapai sasaran-sasaran atau tujuan yang telah ditentukan melalui pemanfaatan sumber daya manusia dan sumber-sumber lainnya.

Kehadiran manajemen dalam suatu organisasi bertujuan untuk melaksanakan kegiatan agar suatu tujuan tercapai secara efektif dan efisien (Jaja Jahari dan Amirullah Sarbini, 2013: 6). Apabila fungsi-fungsi manajemen berjalan dengan optimal, maka dalam penyelengaraan pendidikan akan 
berjalan lancar. Pendidikan yang melembaga terimplementasi dalam bentuk sekolah, madrasah dan pesantren.

Manajemen pendidikan Islam menurut Ramayulis yang dikutip oleh Maisah (2013: 5) adalah suatu proses pemanfaatan semua sumber yang memiliki (umat islam, lembaga pendidikan, atau lainnya), baik perangkat keras maupun lunak. Pemanfaatan tersebut dilakukan melalui kerja sama dengan orang lain secara efektif, efisien, dan produktif untuk mencapai kebahagian dan kesejahtraan dunia dan akhirat.

Pesantren merupakan bagian dari struktur internal pendidikan Islam di Indonesia yang diselenggarakan secara tradisional yang telah menjadikan Islam sebagai cara hidup. Sebagai bagian struktur internal pendidikan Islam Indonesia, pesantren mempumyai kekhasan, terutama dalam fungsi sebagai institusi pendidikan, disamping sebagai lembaga dakwah bimbingan kemasyarakatan, bahkan perjuangan (Amin Haedari, 2004:14)

Pondok pesantren sebagai lembaga pendidikan Islam telah mengalami perkembangan yang sangat pesat. Hal ini ditandai dengan perubahan yang terjadi pada pondok pesantren yakni dengan membuka lembaga pendidikan formal dan didukung dengan kelengkapan fasilitas untuk membangun potensipotensi santri. Namun tetap mempertahankan ciri khas dan keaslian isi (curruculum content) yang sudah ada.

Pondok Pesantren Tahfidz Al-Quran Assalaam Kota Bandung merupakan salah satu dari sekian banyak pesantren yang ada di Kota Bandung. Sebagai sebuah lembaga pendidikan Islam yang berada ditengahtengah masyarakat yang sangat antusias terhadap perubahan, maka tentunya Pondok Pesantren Tahfidz Al-Quran Assalaam Kota Bandung tidak terlepas dari berbagai hal yang merupakan dampak adanya globalisasi. Secara geografis pesantren ini terletak di daerah perkotaan, tentunya dapat dengan mudah mengakses informasi, akan tetapi asimilasi dan akulturasi budaya tidak mudah terjadi.

Pondok Pesantren Tahfidz Al-Quran Assalaam merupakan sistem pondok pesantren yang bertujuan agar santri dapat berakhlak mulia, mandiri dan memiliki kompetensi terlebih dalam menghafal AI-Quran. Adapun yang menjadi prioritas pendidikan di Pondok Pesantren Tahfidz Al-Quran Assalaam adalah penanaman akhlaqul karimah, pembentukan kemandirian santri serta pengembangan potensi santri khususnya dalam menghafal Al-Quran. Pada program ini santri dibimbing oleh para ustadz/ustazah untuk bisa menghafal ayat-ayat yang ada di dalam Al-Quran. Program Tahfidz Al-Quran di Pondok Pesantren Tahfidz AI-Quran Assalaam Kota Bandung sudah terstruktur dengan baik, hal ini dibuktikan mulai dari perencanaan, pelaksanaan, dan evaluasi program tersebut.

Awal perkembangan peminat santri pada pondok pesantren sangat sedikit, namun seiring dengan perkembangan yang dilakukan, maka untuk menarik minat orang tua santri untuk memondokan anaknya di pesantren maka pihak Pondok Pesantren Tahfidz Al-Quran Assalaam Kota Bandung membuka program pendidikan formal setingkat Madrasah Tsanawiyah. Dengan pembelajaran Tahfidz Al-Quran yang terintegrasinya di Madrasah Tsanawiyah. Dengan dibukanya Madrasah Tsanawiyah Assalaam membuat pihak Pondok Pesantren Tahfidz Al-Quran Assalaam Kota Bandung melakukan 
pengorganisasian dengan baik dalam tenaga pendidik dan kependidikan, santri serta pembelajaran santri.

\section{KAJIAN TEORI}

Manajemen berasal dari kata to manage yang berarti mengatur. Pengaturan dilakukan melalui proses dan diatur berdasarkan urutan dari fungsifungsi manajemen itu. Jadi, manajemen itu merupakan suatu proses untuk mewujudkan tujuan yang diinginkan (Hasibuan, 2011:1). Sedangkan menurut Waggner dan Hollenbenck yang dikutip Maisah (2013:1) manajemen adalah suatu proses perencanaan, pengoragnisasian dalam rangka mencapai tujuan melalui pembagian kerja.

Program didefinisikan sebagai suatu unit arau kesatuan kegiatan yang merupakan realisasi atau implementasi dari suatu kebijakan, berlangsung dalam proses yang berkesinambungan, dan terjadi dalam suatu organisasi yang melibatkan sekelompok orang. Ada pengertian penting dan perlu ditekankan dalam menentukan program yaitu, (1) realisasi atau implementasi suatu kebijakan, (2) terjadi dalam kurun waktu yang relatif lama-bukan kegiatan tunggal tetapi jamak berkesinambungan, dan (3) terjadi dalam organisasi yang melibatkan sekelompok orang (Suharsimi dan Cepi, 2009:4).

Program dapat diartikan sebagai kegiatan sebagai kegiatan yang dilakukan oleh perorangan, kelompok, dan/atau organisasi (lembaga) yang memuat komponen-komponen program. Komponen-komponen program itu meliputi tujuan, sasaran, isi dan jenis kegiatan, proses kegiatan, waktu, fasilitas, alat, biaya, organisasi penyelenggara, da lain sebagainya. Sedangkan manajemen program merupakan upaya menerapkan fungsi-fungsi pengelolaan baik untuk setiap kegiatan yang berkaitan dengan pendidikan maupun untuk satuan dan jenis pendidikan (Sudjana, 2004:1-2).

Manajemen program adalah suatu proses perencanaan, pengorganisasian sumber daya manusia dan sumber daya lainnya dalam implementasi suatu kebijakan guna untuk mencapai tujuan yang telah ditentukan melalui pembagian kerja dan dalam kurun waktu yang relatif lama dalam organisasi yang melibatkan sekelompok orang. Manajemen program Tahfidz Al-Quran tidak terlepas dari fungsi-fungsi manajemen diantaranya perencanaan, pengorganisasian, pemotivasian, pengawasan dan evaluasi program.

Perencanaan adalah proses yang sistematis dalam pengambilan keputusan tentang tindakan yang akan dilakukan pada waktu yang akan datang. Disebut sistematis karena perencanaan dilaksanakan dengan menggunakan prinsip-prinsip tertentu. Prinsip-prinsip tersebut mencakup proses pengambilan keputusan, penggunaan pengetahuan dan teknik secara ilmiah, serta tindakan atau kegiatan yang terorganisasi (Sudjana, 2004:56).

Pengorganisasian (program) pendidikan adalah usaha mengintegrasikan manusia dan non-manusia yang diperlukan kedalam suatu kesatuan untuk melaksanakan kegiatan sebagaimana telah direncanakan dalam mencapai tujuan yang ditetapkan terlebih dahulu. Dengan kata lain, pengorganisasian adalah proses kegiatan manajerial untuk membentuk organisasi yang diberi tugas melaksanakan rencana yang telah ditetapkan guna mencapai tujuan organisasi. Adapun tujuan dari pengorganisasian adalah 
membantu orang-orang untuk bekerja sama secara efektif dalam wadah organisasi.

Motivating atau pemotivasian dapat diartikan sebagai upaya pimpinan untuk menggerakan (memotivasi) seseorang atau kelompok orang yang dipimpin dengan menumbuhkan dorongan atau motive dalam diri orang-orang yang dipimpin untuk melakukan tugas atau kegiatan yag diberikan kepadanya sesuai dengan rencana dalam rangka mencapai tujuan organisasi. Dorongan atau motive ada dalam diri seseorang, sedangkan upaya menggerakan (motivasi) sering dilakukan oleh pihak di luar dirinya (Sudjana, 2004:150). Tujuan motivasi mencakup tujuan umum dan tujuan khusus.adapun tujuan khusus motivasi adalah tumbuhnya dorongan pada diri seseorang atau kelompok untuk melakukan tugas atau kegiatan dalam upaya mencapai tujuan organisasi; dan bangkingnya kemauan, keinginan dan harapan pada diri pihak yang dimotivasi sehingga ia atau mereka dapat melakukan keinginan sebagaimana dikehendaki oleh motivator (Sudjana, 2004:153).

Pengawasan sering juga disebut pengendalian yaitu mengadakan pemantauan atau koreksi sehingga bawahan dapat melakukan tugasnya dengan benar sesuai tujuan semula (Badrudin, 2013:17). Pengendalian pengukuran atau perbaikan terhadap pelaksanaan kerja bawahan, agar rencana-rencana yang yang telah dibuat untuk mencapai tujuan-tujuan perusahaan dapat diselenggarakan.

Adapun langkah-langkah pokok pengawasan menurut Sudjana (2004 : 219) dapat dirumuskan sebagai berikut : (1) Menetapkan tolak ukur mengenai hasil pencapaian tujuan dan kegiatan untuk mencapai tujuan tersebut; (2) Mengukur penampilan pelaksana dalam melakukan kegiatan; (3) Membandingkan penampilan pelaksana dengan tolak ukur yang telah ditetapkan; (4) Memperbaiki kegiatan, apabila dipandang perlu, sehingga kegiatan itu sesuai dengan rencana.

Evalusi berasal dari kata evaluation (bahasa Inggris). Kata tersebut diserap ke dalam perbendaharaan istilah bahasa Indonesia dengan tujuan mempertahankan kata aslinya dengan sedikit penyesuaian lafal Indonesia menjasi "evaluasi. Evaluasi adalah kegiatan mengumpulkan informasi tentang bekerjanya sesuatu, yang selanjutnya informasi tersebut digunakan untuk menentukan alternatif yang tepat dalam mengambil sebuah keputusan (Suharsimi dan Cepi, 2009:1-2).

Makna dari evaluasi program itu sendiri mengalami proses pemantapan. Definisi yang terkenal untuk evaluasi program dikemukakan oleh Ralph Tyler, yang mengatakan bahwa evaluasi program adalah proses untuk mengetahui apakah tujuan pendidikan sudah dapat terealisasikan. Sedangkan menurut Cronbach dan Stuffebean yang dikutip Arikunto dan Cepi Safruddin (2009: 5) evaluasi program adalah upaya menyediakan informasi untuk disampaikan kepada pengambil keputusan.

Tahfidz Al-Quran atau menghafal Al-Quran adalah suatu perbuatan yang sangat mulia dan terpuji. Sebab, orang yang menghafalkan AI-Quran merupakan salah satu hamba yang ahlullah dimuka bumi. Itulah sebabnya, tidaklah mudah dalam menghafal Al-Quran; diperlukan metode-metode khusus ketika menghafalkannya (Wiwi, 2014:13). Menghafal Al-Quran adalah fardhu kifayah bagi umat Islam, artinya apabila ada sebagian yang telah 
melaksanakan maka gugurlah kewajiban bagi yang yang lain (Ahmad, 2014: 24).

\section{METODE PENELITIAN}

Pendekatan penelitian yang dilakukan adalah pendekatan kualitatif. Jenis data yang digunakan adalah jenis kualitatif, yaitu data deskriptif berupa kata-kata tertulis atau lisan dari orang-orang dan prilaku yang dapat diambil. Penelitian dilaksanakan di Pondok Pesantren Tahfidz Al-Quran Assalaam beralamat Komplek Mandalajati VI Nomor 132 Rt. 01 Rw. 11 Kelurahan Jatihandap Kecamatan Mandalajati Kota Bandung.

Teknik pengumpulan data melalui wawancara, observasi dan menyalin dokumen. Teknik analisis data terdiri dari beberapa langkah, diantaranya yaitu: 1) unitisasi; 2) Kategorisasi; dan 3) Penafsiran. Teknik pemeriksaan absah data yang dilakukan meliputi: 1) Perpanjang keikutsertaan 2) Ketekunan pengamatan; 3) Triangulasi, triangulasi; 4) Pemeriksaan teman sejawat; 5) Kecukupan referensi; 6) Kajian kasus negatif dilakukan dengan mengumpulkan; 7) Pengecekan anggota; 8) Uraian rinci; 9) Auditing kebergantungan; dan 10) Auditing kepastian,

\section{HASIL DAN PEMBAHASAN}

Pondok Pesantren Tahfidz Al-Quran Assalaam berada di bawah Yayasan Assalaam yang dipimpin oleh $\mathrm{KH}$. Habib Ustman Alaydus dan Pondok Pesantren Tahfidz Al-Quran Assalaam di pimpin oleh Ustadz Abdul Basith, M.Pd. Lokasi pondok pesantren berada di Komplek Mandalajati VI Nomor 132 Rt. 01 Rw. 11 Kelurahan Jatihandap Kecamatan Mandalajati Kota Bandung.

Perkembangan Pondok Pesantren Tahfidz Al-Quran Assalaam tidak terlepas adanya keinginan yang kuat untuk berkembang pesat. Sehingga perkembangan Pondok Pesantren Tahfidz Al-Quran Assalaam memiliki visi yaitu "Membentuk Generasi Qur'ani yang Cendikia, Sholeh, Terampil dan Berakhlak Mulia". Untuk mencapai ketercapaian tersebut Ustadz Abdul Basyit Syaiful menjelaskan misi yang dijalankannya, yaitu a) Melaksanakan pembelajran secara profesional, utuh, menyeluruh dan seimbang, b) Melaksanakan pembelajaran yang mampu memberikan bekal pengetahuan sikap mandiri, berakhlak mulia, terampil dan siap memasuki jenjang pendidikan selanjutnya, c) Melaksankan pembelajaran Al Quran yang terpadu, d) Membangun karakter Islami pada santri dan semua warga sekolah, dan e) Menyiapkan calon Da'i yang tangguh dan handal.

Perencanaan program Tahfidz Al-Quran di Pondok Pesantren Tahfidz AlQuran Assalaam meliputi perencanaan program dan perencanaan pembelajaran Tahfdz Al-Quran. Perencanaan program dilakukan dnegan beberapa tahapan antara lain: analisis kebutuhan santri, peramalan (forcasting), perumusan dan penetapan tujuan, pelaksanaan dan pemantauan (monitoring). Sedangkan pembelajaran Tahfidz Al-Quran dilakukan dengan tiga tahapan diantaranya penetepan alokasi dan tempat pembelajaran, penyusunan program tahunan dan penyusunan program semesteran.

Pengorganisasian adalah suatu proses penentu, pengelompokan, dan pengaturan bermacam-macam aktivitas yang diperlukan untuk mencapai tujuan, menempatkan orang pada setiap aktivitas ini, menyediakan alat-alat 
yang diperlukan, menetapkan wewenang yang secara relatif didelegasikan kepada setiap individu yang akan melakukan aktivitas-aktivitas tersebut.

Pengorganisasian santri dalam program Tahfidz Al-Quran dilakukan dengan mengelompokkan santri menjadi 4 kelas yaitu kelas ibtida, tahsin, tahfidz, dan mumtaz. Pengorganisasian juga dilakukan kepada ustadz/ustadzah yaitu dengan memberikan tugas dan tanggung jawab kepada semua ustadz/ustadzah, pengorganisasian ini disesuaikan juga dengan kemampuan yang dimiliki oleh ustadz/ustadzah. Dengan adanya pembagian tugas dan tanggung jawab kepada setiap ustadz/ustadzah dimungkinkan kegiatan pembelajaran dan tujuan program akan sesuai dengan perencaranaan baik proses maupun kualitasnya.

Motivasi yang diberikan kepada santri seperti diceritakan kisah-kisah para penghafal Quran, keutamaan AI-Quran, manfaat manghafal AI-Quran, dan lain sebagainya. Adapun santri yang mendapatkan motivasi khusus yaitu santri yang memiliki keluhan dalam pembelajaran Tahfidz Al-Quran atau yang lainnya. Selain itu motivasi diberikan kepada santri melalui reward dan punishmen yang diberikan oleh ustadz/ustadzah atau orang tua santri. Sementara motivasi yang diberikan kepada ustadz/ustadzah yaitu motivasi ukhrawi karena mengajar al quran itu adalah panggilan hati juga membangkitkan semangat dari ustadz/ustadzah yang mengajar. Adapun ustadz/ustadzah yang diberikan motivasi yaitu ustadz/ustadzah yang sering tidak ngajar serta ustadz/ustadzah yang double job.

Pengawasan program Tahfidz Al-Quran di Pondok Pesantren Tahfidz Al- Quran Assalaam yaitu dengan cara melakukan pemantauan kegiatan santri dan membimbing hafalan santri serta memonitoring hafalan santri melalui buku evaluasi yang telah diberikan kepada setiap santri. Kegiatan ini berlangsung secara berkelanjutan, agar santri dapat terbimbing dengan baik serta memberikan kedekatan antara ustadz dan santri untuk terus memantau kegiaan santri dengan baik dari sikap, akhlak dan hafalan Al-Quran.

Adapun pengawasan yang dilakukan oleh ustadz/ustadzah yaitu dengan melakukan pengawasan pada saat pembelajaran Tahfidz oleh ustadz/ustadzah yang telah ditentukan pada setiap kelasnya. Kegiatan ini berlangsung sekaligus memantau perkembangan hafalan, tingkah laku, sikap dan untuk penilaian pada saat akhir semester. Pengawasan juga dilakukan di asrama santri, hal ini dilakukan agar santri dapat terbimbing dengan baik serta mendekatkan antara ustadz/ustadzah dengan santri, sehingga santri merasa nyaman tinggal di Pondok.

Evaluasi program di Pondok Pesantren Tahfidz Al-Quran Assalaam yaitu dilakukan dengan cara melihat hasil belajar santri serta kemampuan yang dimiliki oleh santri. Indikator yang telah ditentukan oleh pihak Pondok Pesantren untuk melihat kemampuan santri sesuai dengan kelasnya masing masing. Untuk kelas ibtida kemampuan yang harus dicapai yaitu bisa membaca AlQuran dengan baik dan benar, mengetahui sebagian ilmu tajwid, sifatul huruf serta minimal mempunyai hafalan 1 juz. Kelas tahsin, indikator yang harus dicapai yaitu bacaan Al-Quran nya baik dan benar, mengetahui ilmu tajwid secara keseluruhan beserta dalil-dalilnya, sifatul huruf dan minimal mempunyai hafalan 2 juz. Kelas tahfidz, indikator yang dicapai yaitu membaca AI Quran dengan baik dan benar serta menggunakan muratal yang telah dipelajari, 
mengetahui ilmu tajwid beserta dalilnya, sifatul huruf, nuribat-nuribat Al-Quran, dan target hafalan minimal dalam satu semester 2 juz. Sedangkan Kelas mumtaz, indikator yang haris dicapai sama seperti kelas tahsin, yang membedakan hanya target minimal hafalan dalam satu semester minimal 4 juz.

Selama proses pembelajaran berlangsung, para santri diberikan bimbingan oleh pimpinan Pondok Pesantren dan ustadz/ustadzah untuk terus memperbaiki bacaan AI-Quran dan menambah hafalannya dengan memberikan bimbingan dan pengarahan mengenai IImu Tajwid, Makhorijul Huruf dan Sifatul Huruf. Proses bimbingan yang diberikan kepada santri untuk melancarkan dan memfasihkan bacaan Al-Quran pada saat hafalan selanjutnya. Pelaksanaan bimbimbingan yang dilakukan oleh ustadz/ustadzah tidak membedakan/ mengelompokan santri. Namun, para santri belajar menghafal berdasarkan kemauan dan tekad yang dimilikinya. Selain itu, non tes dilakukan oleh pembimbing dalam menilai keseharian santri dari segi kehadiran, kepribadian, sosial dan keagamaan santri.

Pondok pesantren untuk mengoptimalkan hafalan para santri yaitu dengan melakukan evaluasi mingguan. Evalusi ini berfungsi untuk mengulang hafalan yang telah diperoleh santri dalam satu minggu. Selain itu, santri juga melakukan pengulangan hafalan setiap selesai salat ashar, sebelum subuh dan sebelum hafalan disetorkan kepada Ustadz Abdul Basith atau Ustadz Sidiq.

Pada setiap akhir bulan santri juga akan melakukan tes hafalan dengan cara di sima' (diperdengarkan hafalan Al-Quran dalam waktu satu hari). Disamping itu, teknik non tes juga digunakan untuk mengevalasi santri dari segi sikap dan keterampilan karena di Pondok para ustadz/ustadzah tinggal satu asrama dengan para santri maka santri akan terawasi setiap jamnya.

Proses pembelajaran yang dilakukan oleh ustadz/ustadzah di Pondok Pesantren Tahfidz Al-Quran Assalaam dalam mengoptimalkan pembelajaran untuk santrinya yaitu dengan mangadakan takrir (pengulangan). Kegiatan takrir biasa dilakukan setelah salat ashar kepada pembimbing masing-masing dengan tujuan agar hafalan santri dapat terpelihara. Selain itu, santri bisa menyetokan hafalnnya kepada Pimpinan Pondok Pesantren dengan metode Talaqqi. Metode ini digunakan untuk mengukur kemampuan santri sekaligus mengawasi hafalan Al-Quran santri dan metode ini dilaksanakan setiap satu bulan sekali di mesjid pondok pesantren atau rumah Ustadz Abdul Basith dengan teknis setiap santri mengantri untuk mentalaqqi hafalannya kepada Ustadz Abdul Basith.

Dalam menjalankan suatu program tentunya tidak terlepas dari adanya faktor pendukung dan penghambat yang tentunya akan mempengaruhi hasil dari program Tahfidz Al-Quran. Secara garis besar, faktor-faktor pendukung dalam program Tahfidz Al-Quran di Pondok Pesantren Tahfidz Al-Quran Assalaam Kota Bandung diantaranya: 1) Mendatangkan ustadz/ustadzah dengan kualifikasi hafidzah, dengan latar belakang pendidikan pondok pesantren Al-Quran dan bertanggung jawab membimbing santri sekaligus berperan sebagai orang santri selama berada di pondok pesantren, 2) Orang tua santri yang ikut berperan serta dalam proses perkembangan santri selama di luar pondok pesantren, dan 3) Lingkungan pondok pesantren yang nyaman dan sejuk, jauh dari kebisingan serta lingkungan para penghafal Al-Quran sehingga menambah semangat untuk menghafal Al-Quran. Sekian banyak 
faktor pendukung dalam program Tahfidz Al-Quran, namun jika tidak dibarengi dengan motivasi dan tekad yang kuat dalam diri santri untuk menjadi hafid/hafidzah maka santri tidak memperoleh hasil apapun dalam program Tahfidz Al-Quran ini.

Faktor-faktor penghambat dalam program Tahfidz Al-Quran di Pondok Pesantren Tahfidz Al-Quran Assalaam Kota Bandung diantaranya: 1) Kurangnya motivasi santri dalam menghafal Al-Quran, 2) Sebagian orang tua santri tidak memperhatikan anaknya pada saat ada dirumah, sehingga hafalan santri banyak yang lupa, 3) Lingkungan rumah santri yang kurang kondusif, 4) Santri masih sedikit keteteran dalam pembagian waktu untuk menambah hafalan dan murajaah hafalan, 5) Keinginan santri untuk menambah hafalannya terkadang mengalahkan kewajibannya untuk banyak memuraja'ah hafalannya 6) Santri lebih fokus pada kegitan sekolah dibandingkan pesantren, 7) Tidak semua orang tua santri memperhatikan hafalan santri ketika berada dirumah dan 8) Santri sudah mulai tertarik dengan lawan jenis (pacaran).

Hasil yang diperoleh dari program Tahfidz Al-Quran adalah melahirkan calon santri yang hafidz dan hafidzah yang mempunyai akhlaqul karimah dan berwawasan keislaman. Terdapat beberapa penghargaan atau prestasi yang pernah diraih oleh para santri di Pondok Pesantren Al-Quran Assalaam diantaranya:

a) Juara I MHQ cabang 5 Juz dalam acara Fasnpecta di MAN 2 Kota Bandung

b) Juara I MHQ dalam acara Festifal Muharrom $1439 \mathrm{H}$ PPNH- HAMDA

c) Juara II MHQ Juz 30 dalam acara Assalaam Islamic Festifal 2018 seBandung Raya

d) Juara II MHQ cabang 5 Juz dalam acara Assalaam Islamic Festifal 2018 se-Bandung Raya

Santri melakukan pembelajaran Tahfidz Al-Quran di Pondok Pesantren Tahfidz Al-Quran Assalaam tidak mudah, dibutuhkan keistiqomahan untuk terus mengakaji Al-Quran untuk lebih mendalami metode-metode khusus ketika menghafalkan Al-Quran. Salah satunya santri harus menempuh program semseteran yang telah ditetapkan untuk bisa naik kelas (8.W.b). dalam rengtang satu tahun Pondok Pesantren Tahfidz Al-Quran Assalam telah melakukan kegiatan wisuda ke-3 pada tanggal 07 Juni 2018, santri yang diwisuda sesuai dengan kelas di Madrasah Tsanawiyah. Pondok pesantren Tahfidz Al-Quran Assalaam melaksanakan kegiatan menghafal Al-Quran bertujuan untuk melahirkan hafidz/hafidzah di usia remaja, dan agar santri memiliki akhlakul karimah dalam bertingkah laku sehari-hari. Perubahan yang dirasakan oleh santri ketika sudah masuk ke Pondok Pesantren Tahfidz AlQuran Assalaam, yaitu : 1) Perubahan sikap yang menjadi lebih baik sebelum masuk ke pesantren, 2) Menjadi lebih mandiri dalam berbagai hal, 3) Lebih hormat kepada orang tua, 4) Meningkatkan rasa peduli terhadap sesama, dan 5) Mendapatkan banyak pengetahuan dan pengalaman ketika menghafal AlQuran

\section{SIMPULAN}

Perencanaan Program Tahfidz Al-Quran di Pondok Pesantren Tahfidz Al-Quran Assalaam melalui beberapa tahapan yaitu : perencanaan program 
Tahfidz Al-Quran, pembelajaran Tahfidz Al-Quran dan layanan asrama Tahfidz Al-Quran. Pengorganisasian program Tahfidz Al-Quran di Pondok Pesantren Tahfidz Al-Quran dilaksanakan untuk menentukan siapa saja yang akan melaksanakan tugas, pokok dan fungsi dalam program Tahfidz Al- Quran. Pemotivasian program Tahfidz Al-Quran di Pondok Pesantren Tahfidz Al-Quran Assalaam diberikan kepada santri dan ustadz/ustadzah. Motivasi yang diberikan kepada santri dilakukan melalui kisah-kisah para shabiyah dan kajian keislaman disertai dengan dukungan verbal untuk terus semangat menghafal Al-Quran.

Pengawasan di Pondok Pesantren Tahfidz Al-Quran Assalaam, Ustadz Abdul Basith melakukan pemantauan secara langsung kepada santri dan ustadz/ustadzah dalam program Tahfidz Al-Quran. Evaluasi progam Tahfidz AlQuran dilakukan untuk melihat sejauh mana ketercapaian dalam mencapai tujuan program. Evalusi tersebut mencakup evalusi hasil belajar dan evalusi proses pembelajaran. Evaluasi hasil belajar dilakukan dalam bentuk tes tulis dan lisan, dan dinyatakan lulus dalam hafalan Al-Quran.

Faktor pendukung dalam program Tahfidz Al-Quran ini antara lain ustadz/ustadzah yang hafidz/hafidzah yang senantiasa membimbing santri setiap harinya. Keinginan kuat dari santri yang mendorong semangat ustadz/ustadzah untuk meberikan memotivasi dan semangat kepada para santri dalam menghafal Al-Quran serta di dukung lingkungan yang kondusif unutk proses pembelajaran. Faktor penghambat dalam program ini antara lain santri mudah bosen dalam proses pembelajaran, tidak istiqomah, kebanyakan tidak fokus pada saat menghafal Al-Quran, santri belum bisa mengatur waktu untuk menghafal dan murajaah hafalan dan santri sudah mulai tertarik terhadap lawan jenis.

Hasil yang diperoleh Pondok Pesantren Tahfidz Al-Quran Assalaam dapat dilihat dari prestasi yang diperoleh santri baik dalam mengikuti perlombaan dan prestasi di sekolah. Selain itu, lulusan Pondok Pesantren Tahfidz Al-Quran Assalaam mampu menerapkan ilmu yang telah dipelajarainya serta mampu memberikan motivasi kepada masyarakat untuk giat menghafal Al-Quran.

\section{REFERENSI}

Arikunto, Suharsimi dan Safruddin, Cepi. (2009). Evaluasi Program Pendidikan. Bandung: PT Bumi Aksara.

Badrudin. (2013). Dasar-Dasar Manajemen. Bandung: Alfabeta.

Baduwailan, Ahmad, Bin Salim. (2014). Cara Mudah dan Cepat Hafal Al-Quran. Solo: Kiswah Media.

Basri, Hasan. (2013). Landasan Pendidikan. Bandung: Pustaka Setia.UU RI No. 14 Tahun 2005 \& Permendiknas No. 11 Tahun 2011 Bandung: Citra Umbara.

Haedari, Amin. dkk. (2004). Masa Depan Pesantren Dalam Tantangan Modernistas dan Tantangan Komplesitas Global. Jakaarta: IRD Press

Hasibuan, Malayu S.P. (2011). Manajemen: Dasar, Pengertian, dan Masalah. Jakarta: Bumi Aksara.

Jahari, Jaja dan Syarbini, Amirullah. (2013). Manajemen Madrasah Teori Strategi dan Implementasi. Bandung: Alfabeta. 
Y. Suryana, Dian, S. Nuraeni

Maisah. 2013. Manajemen Pendidikan. Jakarta: Referensi.

Sudjana, S. H. Djudju. (2004). Manajemen Program Pendidikan untuk Pendidikan Nonformal dan Pengembangan Sumber Daya Manusia. Bandung: Falah Production.

Wahid, Wiwi, Alawiyah. (2014). Cara Cepat Bisa Menghafal Al-Qur'an. Jogjakarta: DIVA. 